\title{
Grammatical Errors Committed by the English Department Students in Writing an Argumentative Essay
}

\author{
Armila Depega $^{1^{*}}$ and Jufrizal ${ }^{2}$ \\ I*Universitas Negeri Padang, Padang, Indonesia, armiladepega@gmail.com \\ ${ }^{2}$ Universitas Negeri Padang, Padang, Indonesia, jufely@yahoo.com
}

\begin{abstract}
This research aims at investigating the types and causes of grammatical errors made by the English department students. In learning writing essay, the students are expected to be able to write a good essay with some aspects, in the fact they still had problems even errors in writing. Error is common for English as foreign language students, but if the errors are not detected earlier, the uncorrected errors may become a permanent error or "fossilization". Hence, the errors should be detected. The type of the research is a descriptive research. The data were all types and causes of grammatical errors made by the students in writing argumentative essay. The source of data was the results of students writing test. Then, the sample was the fourth semester students of English department of Universitas Negeri Padang consisting of 20 students. The data were collected by using writing test. The findings show that the students have some errors in writing argumentative essay. They are misordering errors, omission errors, misformation errors, and addition errors of some grammatical aspects; verb tenses, modal auxiliaries, passive voice, "be \& have", gerund, singular and plural, pronoun and preposition. Then, the causes of grammatical errors are interlingual error and intralingual errors which divided into four indicators; false concept hypothesized, ignorance of rule restriction, overgeneralization, and incomplete application of rule.
\end{abstract}

\section{Keywords: Grammatical Error, Causes of Error, Argumentative Essay}

\section{INTRODUCTION}

Writing is a productive skill that should be mastered by the students, especially for English Department students. They should have good productive skills. There are two productive skills in language learning. Particularly, in writing, the students should pay attention toward a number of language aspects such as grammar, model texts, sounds, and meaning. Harmer (2002) says that written text has several conventions that separate it out from speaking. He also adds another conventions; spelling, and layout, issues of letter, word, and text formation, manifested by handwriting, and punctuation. Most of the college students often consider grammar as one of difficult aspects to be understood in English. Grammar is such a significant thing to apply in learning language. It is a part of language which has to be learned by the students. The students have to produce the sentences grammatically correct so that their writing can be easily understood by the readers.

Making errors and mistakes in writing English are commonly done by the second and foreign language students. Error is actually very different from mistake. Brown (2007:257) defines that a mistake refers to a performance error meant a random guess or a "slip", while an error is a noticeable deviation done by a person reflecting the competence of the learner. It implies that an error is a deviation which is done by the learner because they do not know the rules and they will make the errors repetitively. Therefore, the students are judged having error when they repetitively make errors in their writings.

In writing especially for English students, writing essay is one of the most meaningful ways to make students master in writing skill. Kathleen (2015) says that there are five types of essays learned by the college students. They are narrative essay, descriptive essay, cause and effect essay, argumentative essay, comparison and contrast essay. In this research, the researcher chose an argumentative essay to be researched. Argumentative essay is an appropriate essay for college students because they can express their thoughts, ideas, or opinions in writing subject, then they can prove their opinion by giving evidence and sample about an issue.

In the field, there were still many errors done by English students especially in writing an argumentative essay. Actually, error is common for the English as foreign language students. However, if the errors are not concerned and detected earlier, the uncorrected errors may become a permanent error or "fossilization". Errors are fossilized since they are not detected earlier as proposed by Myers and Scotton (2006:358) who state that the earlier 
errors are serious matter to be emphasized because it remains in the learners' memory that leads to fossilization of the errors. Therefore, the errors should be detected and corrected earlier so the students can know their errors they make in writing. If not, the tendency to commit the errors is greater while the tendency for the errors to be noticed is less of course because the opportunity to notice or get the errors corrected is less.

There are two objectives of this research; first, to investigate the types of grammatical errors made by the English Department students. Second is to investigate the causes of grammatical errors done by the English Department students at UNP in writing argumentative essay. Then, the research is expected to give a helpful contribution. The results can be the reference theories for further research and give knowledge for the readers in general about the grammatical errors in writing.

\section{METHOD}

Type of research was a descriptive qualitative research. Suharsimi (2005:234) also adds that descriptive research is a research with the view to collect information and to describe about a variable or a phenomenon. The data of this research were the sentences which carry the grammatical errors and causes of error from the English department students of UNP in writing argumentative essay. The researcher used cluster random sampling technique to select group of population as sample randomly. The sample size for descriptive research should be at least 10 percent of the population (Gay, 2009). Thus, the researcher took 20 students of 140 students. It was already more than 10 percent as suggested.

In this research, the researcher used writing test to obtain the data. The data were obtained from the students' writing test on May $7^{\text {th }}, 2019$. To test validity of the instrument, the researcher makes sure whether argumentative essay was suitable with the materials that were given by the lecturer or not.

Then, to answer the first research question, the data were analyzed in few steps. First, the researcher omitted the students' name in their writings. Then, the researcher coded students' paper. After that, the researcher read the students' writing of argumentative essay to find the grammatical errors in those writings.

After finding the sentences had errors which were repetitively made by the student in writing, the researcher underlined and gave code for those in students' argumentative essay. After that, the researcher classified and grouped the grammatical errors into the types of errors based on theory of surface strategy taxonomy suggested by Dulay, et al (1982:150). The errors were corrected and then reconstructed by using the result of the error's analysis and the correct English structure. Next, the researcher analyzed and classified the sentences which are categorized error into the theory of Ellis \& Barkhuizen (2005:65) about the causes of errors. The indicators are in the following table.
Table 1. Causes of Grammatical Error

\begin{tabular}{|c|l|l|}
\hline No. & \multicolumn{1}{|c|}{$\begin{array}{c}\text { Cause of } \\
\text { Error }\end{array}$} & \multicolumn{1}{|c|}{ Indicator } \\
\hline 1 & $\begin{array}{l}\text { Interlingual } \\
\text { Error }\end{array}$ & Language transfer \\
\hline 2 & $\begin{array}{l}\text { Intralingual } \\
\text { Error }\end{array}$ & False-concept hypothesized \\
\cline { 3 - 3 } & $\begin{array}{l}\text { Ignorance of rule } \\
\text { restriction }\end{array}$ \\
& & $\begin{array}{l}\text { Overgeneralization } \\
\text { Incomplete application of } \\
\text { rule }\end{array}$ \\
\hline
\end{tabular}

\section{RESULTS AND DISCUSSION}

1. The Students' Grammatical Error in Writing an Argumentative Essay

There were four types of errors based on Dulay's Surface Strategy Taxonomy used in this research; misordering error, omission error, misformation error, and addition error. The errors were found in the form of misordering, omission, misformation, and addition of verb tenses, modal auxiliaries, passive voice, be and have, gerund, singular and plural, pronoun, and preposition. The results were in the following.

\section{1) Misordering Error}

The last type of errors based on surface taxonomy was misordering error. Based on the data collected, there were 4 misordering errors in the students' writings. They are misordering errors of passive voice, "Be", gerund, and pronoun. The following example is a misordering error of passive voice.

\section{Student 8 Line 7:}

"In this passage will be explained the reasons why they agree and disagree with the using of smartphone.

In this case, the subject should not "in this passage". It should be "the reason why they agree and disagree with the using of smartphone". The reconstructed sentence is "the reasons why they agree and disagree with the using of smartphone will be explained in this passage."

\section{2) Omission Error}

The first type of errors for finding out the students' grammatical error was omission. There were 26 omission errors in students' writing. First, the students made 3 omission error of passive voice. To construct the passive voice sentence, the subject should be followed by a "be" with verb past participle (V3). For example:

\section{Student 5 Line 4:}

"There are some games that $\theta$ considered as a violent video game." 
The sentence of student 5 cannot be categorized as a well-formed sentence since there was omission of item. To make passive voice, the second clause should have "be". So, it should be "There are some games that are considered as a violent video game."

Then, the students committed the omission error of "Be". The number of students' errors was 11 omission errors. It was found that the students omitted "be" that should appear in a wellformed sentence. The absence of "be" caused the sentence ungrammatical, such as:

\section{Student 8 Line 39:}

"If you $\Theta$ careful, you will $\Theta$ safe from the negative effect."

The sentence of student 8 cannot be categorized as a well-formed sentence since there is no "be" after subject particularly in nominal sentence. To make it as a well-formed sentence, "be "should be attached after subject. Thus, it should be "If you are careful, you will be safe from the negative effect.

Next, it was found that the students made 3 omission error of pronoun and 9 omission errors of preposition. In conclusion, the students made omission errors of passive voice, omission errors of "be", pronoun and preposition.

\section{3) Misformation Error}

Misformation error was also one of types of errors based on surface strategy taxonomy. The number of the students' misformation errors was 134 misformation errors. First the students committed misformation errors of verb tenses. The number of students' misformation errors was 51 errors. For example:

Student 4 Line 1:

"Teacher is someone who teach knowledge to student."

$$
M f . V t
$$

In the example above, the tense form used is simple present tense. There is noun clause in that sentence which has verb and complement. In verb form of simple present, most regular verbs use $V_{1}$, except in the third-person singular (which verb ends in -s/es). Thus, the sentence should be: "Teacher is someone who teaches knowledge to students".

Moreover, the students also committed misformation errors of modal auxiliaries. The number of students' misformation error was 24 errors. The example below is one of the misformation errors of modal auxiliaries.
Student 8 Line 18:

You can listening to the music, playing games and watching movies or video through the smartphone.

Mf.MA

In the example above, the verbs (listening, playing and watching) after modal (can) are not base verb form $\left(\mathrm{V}_{1}\right)$. Thus, all verbs in the sentence should be changed into $\mathrm{V}_{1}$ (listen, play, and watch). The correct sentence is: "You can listen to the music, play games and watch movies or videos through the smartphone".

In addition, the students also committed 4 misformation errors of passive voice and 10 misformation errors of "Be \& Have". There were 7 misformation errors of "be" and 3 misformation errors of "have". Next, the students also made 8 misformation errors of gerund.

Moreover, the students also committed 28 misformation error of singular and plural and 2 misformation errors of pronoun. Also, students had 7 misformation of errors.

In conclusion, the students made misformation errors in writing argumentative essay. It occurred on several grammatical aspects; verb tenses, modal auxiliaries, passive voice, "Be" \& Have, gerund, singular \& plural, pronoun, and preposition.

\section{4) Addition Error}

The second type of errors for finding out the students' grammatical error was addition. Based on the data collected, there were 16 addition errors in students' writing. The students committed 10 addition errors of "Be". For example:

Student 5 Line 3:

"Children and students are usually play some games on the internet."

$$
\text { Abe Verb }
$$

Actually, the sentence above has a main verb (play) which indicates as verbal sentence. However, there is "be" (are) comes first after subject in that sentence in which usually indicates as nominal sentence. Meanwhile, the verbal sentence consists of subject following by verb. Thus, "be" should be removed there. Then, the correct sentence is: "Children and students play some games on the Internet."

Then, the students also committed the addition error of pronoun. Also, the students also committed addition errors of preposition. The number of students' error was 5 addition errors of preposition. For example:

Student 5 Line 6: children."

"For violent games could negatively affect APrep 
To make an appropriate sentence, the preposition (for) should be deleted. Then, the correct sentence is: "Violent games could negatively affect children". As we know, prepositional phrase cannot be used as subject. Therefore, it can be said that the students had the addition errors of preposition.

To sum up, the students had addition error in their writings. First, the students committed addition error of "be" in writing argumentative essay. Second, they made addition error of pronoun. Last, they made addition error of preposition in writing their argumentative essay.

Therefore, related to other relevant research finding done by Andi (2017) on Morphological Errors made by the sixth semester students of English and Literature Department of Adab and Humanities Faculty in writing Essay, where there are the types of errors found in students' writing (omission, addition, and misformation). In this research, such errors are also found. Therefore, it can be said that the college students tended to make grammatical errors on these three types of error in writing.

\section{Causes of Errors}

Since there were some grammatical errors done by the students in writing argumentative essay, there must be some causes that resulted the errors in students' writings. There were some indicators used to find out the causes. The indicators were interlingual transfer and intralingual transfer (Ellis \& Barkhuizen, 2005).

\section{1) Interlingual Error (Language Transfer)}

Interlingual Error was the first cause which resulted the students committed the grammatical errors in writing argumentative essay. As the example, there was an example found in student' writing, "Today, many children have to spend hours every evening doing homework." (S13, L1)

Based on the example above, the sentence was written in Indonesian style in which it was the students' first language. It can be seen that the position adverb of time was at the middle of sentence. Actually, the gerund should come earlier than adverb. Then, the structure should be exchanged into: Today, many children have to spend hours doing homework every evening.

Based on the findings obtained, the students were influenced by their mother tongue, It can be seen from the sentence they construct in which they literally write the sentence into target language. Suhono (2016) finds that the sources of errors of his research were mother-tongue influence (interlingual errors). It was influenced by the native language that interferes with target language learning. It means, an error occurred because there is confusion between mother language and target language structurally.

\section{2) Intralingual Errors}

In intralingual errors, there were four causes of error found. They were false concept hypothesized, ignorance of rule restriction, overgeneralization, and incomplete application of rule. First is the false concept hypothesized. Some students misinterpret the using of grammatical rules of target language in writing. It could be seen form their writings in which they had misformation errors of all grammatical elements in this research. This cause was characterized by misconception of the difference in the target language. It can be seen in the following example:

"Violent video game are not good for children growth and students' attitude (S5, L23)."

The form of "be" was influenced by the subject. The subject of the example above is singular noun. If the subject is singular, "be" should be singular too. Then, "be" should be used for singular subject in simple present is "is". Thus, the correct one is: "Violent video game is not good for children' growth and students' attitudes." The false concept hypothesized factor resulted 134 misformation errors of all types of errors found in students' writing.

Second, ignorance of rule restriction was also a cause of error found in this research. Related to four types of errors found, ignorance of rule restriction resulted misordering errors. The errors occurred due to the students did not apply the rules of target language. Thus, ignorance of rule restriction is included as a cause of students' grammatical errors in writing argumentative essay.

The third cause is overgeneralization. Some students generalize the grammar. It can be seen in the following example:

"Children and students are usually play some games on the b internet. (S5, L3)

From the example, the students tend to generalize the verb for simple present tense. The correct sentence is: Children and students play some games on the Internet. The cause of overgeneralization results 17 addition errors of all types of errors found in students' writings

The fourth cause found in this research was incomplete application of rule. Some students omitted the items that should exist in the sentence. It could be seen form their writings. This causes happened because the students neglect the rules which need to be used in the sentence. The incomplete application of rules factor results 26 omission errors.

This finding is quite in line with the result of the research conducted by Paradise (2018) who found that the major causes of errors were intralingual and interlingual factors. The causes of students' error are not only the interference of 
mother tongue to the target language but also the complicated rules of the target language. The error occurred during learning process of target language while the learners have not really obtained the knowledge such grammar. For the reasons, the lecturers have to find out a good teaching method to decrease the students' errors.

\section{CONCLUSION}

Based on 180 errors analyzed, it was found that the English Department students of Universitas Negeri Padang made four types of errors in writing argumentative essay. They were misordering errors, omission errors, misformation errors, and addition errors. Dealing with grammatical points, it was found that the students made the four errors of the use of verb tenses, modal auxiliaries, passive voice, "Be and Have", gerund, singular and plural, pronoun, and preposition. Moreover, more than one type occurred in an essay. Deeply, these errors occurred because two major factors. They were interlingual factor and intralingual factor that divided into four types: false concept hypothesized, ignorance of rule restriction, overgeneralization and incomplete application of rule.

There are some implications related to the students' grammatical errors and rhetorical pattern of students' argumentative essay. First, the teacher gives more exercises for the students in the class. Thus, the teacher does not only give the theory of grammar but also a chance for students to practice.

\section{ACKNOWLEDGMENTS}

The researcher would like to express the appreciation and gratitude to the advisor, Prof. Dr. Jufrizal, M.Hum for his continuous supports, encouragement, and sincere assistance. An abundance of appreciation are also addressed to the examiners Prof. Dr. Hermawati Syarif, M.Hum., and Dr. Hamzah, M.A. Their ideas and critical comments have helped the accomplishment of this research.

\section{REFERENCES}

[1] Andi, Ika. (2017). Morphological Errors Made by the Sixth Semester Students in English and Literature Department of Adab and Humanities Faculty in Writing Essay. Unpublished

[2] Brown, H.D. (2007). Principles of Language Learning and Teaching. $5^{\text {th }}$ edition. San Fransisco: Longman Publishing Group.

[3] Dulay, H., Burt, M., \& Krashen, S. (1982). Language Two. New York: Oxford University.

[4] Ellis, Rod., \& Barkhuizen. (2005). Analyzing Learner Language. Oxford: Oxford University Press.

[5] Gay, L.R., \& Airasian, P. (2009). Educational Research: Competencies for Analysis and Application. New Jersey: Prentice-Hall Company.
[6] Harmer, Jeremy. (2002). The Practice of English Language Teaching $3^{\text {rd }}$ Edition. London: Longman.

[7] Kathleen, T. McWhorter. (2015). Successful College Writing: Skill, Strategies, Learning Styles. $2^{\text {th }}$ edition.

[8] Myers, Carol., \& Scotton. (2006). Multiple Voices: An Introduction to Bilingualism. Victoria: Blackwell Publishing.

[9] Paradise. (2018). An Analysis of the Second Year English Department Students' Errors in Using Passive Voice in the Academic Writing Subject of Universitas Negeri Padang. Journal of English Language Teaching Volume 7 No.3. ISSN 23023198. Published by English Language Teaching Study Program of FBS Universitas Negeri Padang.

[10] Suharsimi, Arikunto. (2005). Prosedur Penelitian Suatu Pendekatan Praktik. Jakarta: PT. Rineka Cipta.

[11] Suhono., 2016. Surface Strategy Taxonomy on the EFL Students' Composition: A Study of Error Analysis. 